\title{
UTERINE RUPTURE IN THIRD TRIMESTER OF PREGNANCY FOLLOWING CORNUAL RESECTION DUE TO ECTOPIC PREGNANCY
}

\author{
Vesna Košec, Marijo Čukelj, Ivka Djaković and Dražan Butorac \\ Department of Gynecology and Obstetrics, Sestre milosrdnice University Hospital Centre, \\ Zagreb, Croatia
}

\begin{abstract}
SUMMARY - Uterine rupture during pregnancy is a critical obstetric complication associated with maternal and fetal mortality and morbidity. The risk is increased in patients with a history of previous uterine surgery including cesarean section, myomectomy, salpingectomy, as well as uterine and placental anomalies and polyhydramnios. It can also occur spontaneously. We present a case of uterine rupture in the early third trimester in a woman who had undergone previous laparoscopic removal of the left fallopian tube due to sactosalpinx and laparotomic removal of left uterine horn due to ectopic pregnancy.
\end{abstract}

Key words: Pregnancy; Third trimester; Uterine rupture; Cornual resection; Salpingectomy

\section{Introduction}

Uterine rupture can occur at any time during pregnancy with increased risk in patients with a history of previous uterine surgery including cesarean section, myomectomy, uterine and placental anomalies, polyhydramnios, and in rare cases, occurring spontaneous$1 y^{1-5}$. This event is rare, life threatening and estimated at $0.03 \%$ of pregnancies in developed countries ${ }^{6}$.

It is a serious obstetric complication associated with maternal and fetal morbidity and mortality. Early diagnosis and treatment are crucial for appropriate and timely action. Multidisciplinary approach is needed in order to achieve better results ${ }^{3}$.

We present a case of spontaneous uterine rupture that occurred in the early third trimester in a woman who had previously undergone laparoscopic removal of the left fallopian tube due to sactosalpinx and laparotomic removal of left uterine horn due to ectopic pregnancy.

Correspondence to: Marijo Čukelj, MD, Department of Gynecology and Obstetrics, Sestre milosrdnice University Hospital Centre, Vinogradska c. 29, HR-10000 Zagreb, Croatia

E-mail: marijo.cukelj@gmail.com

Received November 24, 2016, accepted December 20, 2017

\section{Case Report}

A 27-year-old secundigravida was admitted to our department in $32^{\text {nd }}$ week of pregnancy, presenting with left abdominal pain initially attributed to urinary infection. In 2009, she underwent laparoscopic left sided salpingectomy due to sactosalpinx. Five years later, laparotomy with cornual resection was performed due to interstitial ectopic pregnancy. After the initial laboratory assessment indicated increased inflammatory parameters and possible urinary infection, intravenous antibiotic treatment was started. She was examined by a urologist who diagnosed mild right-sided hydronephrosis with normal findings contralaterally. Due to gestational diabetes, diabetic diet was introduced, and her glycemic profile was normal. On day 8 of hospitalization, she started to complain of irregular contractions and intravenous tocolysis was administered. Cardiotocography (CTG) revealed bradycardia up to 70 beats per minute. The patient was then monitored continuously by CTG, which showed fetal tachycardia up to 170 beats per minute, with early decelerations up to 130 beats per minute. Since CTG findings were nonspecific, additional diagnostic workup followed. Ultrasound examination showed a collection of fluid in the 
upper right abdomen accompanied by tenderness in the previous scar area upon external manual compression of the uterus. Urgent cesarean section was performed due to suspected uterine rupture. Intraoperatively, a $6 \mathrm{~cm}$ long crater shaped uterine rupture was found (Fig. 1) on the uterine fundus. A preterm male newborn weighing 1930 grams, $41 \mathrm{~cm}$ long and Apgar score 6 and 7 was delivered. Uterine rupture was reconstructed with two-layer single sutures. On postoperative day 3 , surgical drain was removed and on postoperative day 4 the patient was discharged with recommendation of oral iron replacement therapy.

\section{Discussion}

It is difficult to compare the pregnancy related uterine transformation with functional or morphological changes in any other organ. In a non-pregnant woman, the uterus weighs approximately 70 grams and is almost solid, except for a cavity of $10 \mathrm{~mL}$ or less, but at term this organ weighs nearly 1100 grams, with a total volume including amniotic fluid, placenta and fetus reaching almost 5 liters. In extreme cases, such as multiple pregnancies or pregnancies complicated by polyhydramnios, the volume may be 20 liters or more ${ }^{7}$. This represents a capacity increase of 1000 times compared to the non-pregnant state. This can cause significant complications when previous structural damage to the uterine tissue has been incurred through surgery.

It is reported that spontaneous rupture of an unscarred uterus occurs in 1 per 15,000 pregnancies ${ }^{8}$. It is often related to high parity, abnormal placentation, uterine anomalies, obstetric maneuvers, malpresentation, tachysystole, injudicious use of oxytocin, uterine diverticula, and chronic corticosteroid use ${ }^{3-5,9,10}$. Ruptures can occur spontaneously, although they occur more often during contractions. In most cases, it occurs in advanced pregnancy ${ }^{3,11}$. Nonspecific pain episodes, fetal asphyxia and abnormal CTG findings occurring in third trimester may easily be attributed to numerous other pathologic conditions even in a hospitalized patient due to diverse and misleading symptom presentation. Cornual pregnancy (implantation near the utero-tubal junction) is a rare type of ectopic pregnancy and may cause uterine cornual dilatation ${ }^{12}$.

Standard surgical therapy for interstitial pregnancy is laparotomy followed by resection of the cornual por- tion of the uterus or hysterectomy ${ }^{13}$. The latest advances in laparoscopic surgery have enabled this condition be resolved laparoscopically as well. Methotrexate pharmacotherapy is also available ${ }^{14-18}$. Hysteroscopic methotrexate injection under ultrasonographic guidance has also been described as a treatment option ${ }^{19}$.

Laparoscopy has become the gold standard in various uterine pathologic conditions. However, uterine rupture during subsequent pregnancies is a wellknown complication of laparoscopy ${ }^{20}$, as in our patient.

Hemostasis by laparoscopic electrocoagulation may cause scar tissue formation in the uterine wall and maladaptation to future changes in size of the pregnant uterus. When scarring occurs in the uterine fundus, strong uterine contractions related to that segment may expose structural damage inflicted by previous procedures ${ }^{21}$. All of the issues discussed previously may be considered as probable causes of uterine rupture.

\section{Conclusion}

The risk of uterine rupture in pregnancies following previous surgical treatment of interstitial pregnancy remains unclear, warranting close monitoring of these women during pregnancy. Patients should be informed on the early signs and symptoms of uterine rupture, thus increasing chances of early diagnosis and treatment. Uterine rupture can cause fetal demise and severe maternal morbidity, including hysterectomy in severe cases. Nonspecific pain episodes occurring in third trimester should be taken into special consideration, as symptoms may be diverse and misleading. In this case report, the importance of close follow-up of a pregnant patient with previous uterine surgery is stressed.

\section{References}

1. Pontis A, Prasciolu C, Litta P, Angioni S. Uterine rupture in pregnancy: two case reports and review of literature. Clin Exp Obstet Gynecol. 2016;43(2):304-9.

2. Sayed Ahmed WA, Habash YH, Hamdy MA, Ghoneim HM. Rupture of the pregnant uterus - a 20-year review. J Matern Fetal Neonatal Med. 2016 Aug 23:1-6. [Epub ahead of print]. doi: 10.1080/14767058.2016.1219997.

3. Djaković I, Rudman SS, Kosec V. Uterine rupture following myomectomy in third trimester. Acta Clin Croat. 2015;54 (4):521-4.

4. Vernekar M, Rajib R. Unscarred uterine rupture: a retrospective analysis. J Obstet Gynaecol India. 2016;66(Suppl 1):51-4. doi: 10.1007/s13224-015-0769-7. 
5. Lovelace D. Congenital uterine anomalies and uterine rupture. J Midwifery Womens Health. 2016;61(4):501-6. doi: 10.1111/ jmwh.12423.

6. Hofmeyr GJ, Say L, Gülmezoglu AM. WHO systematic review of maternal mortality and morbidity: the prevalence of uterine rupture. BJOG. 2005;112:1221-8. doi: 10.1111/j.14710528.2005.00725.x.

7. Cunningham FG, Leveno KJ, Bloom SL, Spong CY, Dashe JS, Hoffman BL, et al. Maternal physiology. In: Williams Obstetrics, $24^{\text {th }}$ edition: United States: McGraw-Hill Companies, Inc., 2014; p 46.

8. Sallam AH, Preston J. Idiopathic uterine perforation in late pregnancy. J Obstet Gynaecol. 2002;22:317. doi: 10.1080/014 43610252971203.

9. Uzun I, Yildirim A, Kalelioglu I, Has R. Spontaneous rupture of unscarred uterus at 27 weeks of gestation. Arch Gynecol Obstet. 2010;281(6):999-1001. doi: 10.1007/s00404-0091321-8.

10. Schrinsky DC, Benson RC. Rupture of the pregnant uterus: a review. Obstet Gynecol Surv. 1978;33(4):217-32. doi: 10.1097 /00006254-197804000-00001.

11. Young-Joon Park, Ki-Young Ryu, Jong-In Lee, and Moon-I1 Park. Spontaneous uterine rupture in the first trimester: a case report. J Korean Med Sci. 2005;20(6):1079-81. doi: 10.3346/ jkms.2005.20.6.1079

12. Chen CD, Chen SU, Chao KH, Wu MY, Ho HN, Yang YS. Cornual pregnancy after IVF-ET. A report of three cases. J Reprod Med. 1998;43(4):393-6.

13. Grobman WA, Milad MP. Conservative laparoscopic management of a large cornual ectopic pregnancy. Hum Reprod. 1998;13:2002-4. doi: 10.1093/humrep/13.7.2002.
14. Said TH. Laparoscopic management of interstitial ectopic using simple and safe technique: case series and review of literature. J Obstet Gynaecol India. 2016;66(Suppl 1):482-7. doi: 10.1007/s13224-016-0862-6.

15. Nirgianakis K, Papadia A, Grandi G, McKinnon B, Bolla D, Mueller MD. Laparoscopic management of ectopic pregnancies: a comparison between interstitial and "more distal" tubal pregnancies. Arch Gynecol Obstet. 2016 Aug 31. [Epub ahead of print] doi: 10.1007/s00404-016-4191-x.

16. Kim MJ, Jung YW, Cha JH, Seok HH, Han JE, Seong SJ, Kim YS. Successful management of heterotopic cornual pregnancy with laparoscopic cornual resection. Eur J Obstet Gynecol Reprod Biol. 2016;203:199-203. doi: 10.1016/j.ejogrb.2016. 04.026 .

17. Faioli R, Berretta R, Dall'Asta A, Di Serio M, Galli L, Monica $\mathrm{M}$, Frusca T. Endoloop technique for laparoscopic cornuectomy: a safe and effective approach for the treatment of interstitial pregnancy. J Obstet Gynaecol Res. 2016;42(8):1034-7. doi: 10.1111/jog.13005.

18. Marret H, Fauconnier A, Dubernard G, Misme H, Lagarce L, Lesavre $\mathrm{M}$, et al. Overview and guidelines of off-label use of methotrexate in ectopic pregnancy: report by CNGOF. Eur J Obstet Gynecol Reprod Biol. 2016;205:105-9. doi: 10.1016/j. ejogrb.2016.07.489.

19. Leggieri C, Guasina F, Casadio P, Arena A, Pilu G, Seracchioli R. Hysteroscopic methotrexate injection under ultrasonographic guidance for interstitial pregnancy. J Minim Invasive Gynecol. 2016;23(7):1195-9. doi: 10.1016/j.jmig.2016.07.015

20. Dubuisson JB, Chavet X, Chapron C, Gregorakis SS, Morice P. Uterine rupture during pregnancy after laparoscopic myomectomy. Hum Reprod. 1995;10(6):1475-7.

21. Kuvačić I. Patologija trudova. In: Kuvačić I, ed. Porodništvo. Zagreb: Medicinska naklada; 2009:445-7. (in Croatian)

\title{
RUPTURA UTERUSA U POSLJEDNJEM TRIMESTRU NAKON RESEKCIJE ROGA MATERNICE ZBOG EKTOPIČNE TRUDNOĆE
}

\author{
V. Košec, M. Čukelj, I. Djaković i D. Butorac
}

Ruptura maternice u trudnoći teška je opstetrička komplikacija povezana sa značajnom maternalnom i fetalnom smrtnošću. Rizik raste kod žena s prethodnom uterotomijom koja uključuje carski rez, miomektomiju, salpingektomiju, ali i različite anomalije posteljice i maternice, polihidramnij, a u rijetkim slučajevima može nastati i spontano. Prikazujemo slučaj rupture maternice u ranom trećem trimestru trudnice koja je prethodno imala lijevostranu salpingektomiju zbog saktosalpinksa učinjenu laparoskopskim putem i resekciju lijevog roga kao terapiju ektopične trudnoće laparotomijom.

Ključne riječi: Trudnoća; Posljednji trimestar; Ruptura maternice; Resekcija roga maternice; Salpingektomija 